\title{
LATE MIOCENE MAUREMYS (TESTUDINES, GEOEMYDIDAE) FROM TUSCANY (ITALY): EVIDENCE OF TERRAPIN PERSISTENCE AFTER A MAMMAL TURNOVER
}

\author{
FRANCESCO CHESI, MASSIMO DELFINO, AND LORENZO ROOK \\ Dipartimento di Scienze della Terra, Università di Firenze, Via G. La Pira 4, I-50121 Firenze, Italy; <francesco.chesi@unifi.it>; \\ $<$ massimo.delfino@unifi.it>; <lorenzo.rook@unifi.it>
}

\begin{abstract}
The occurrence of freshwater turtle remains in the late Miocene lignites of southern Tuscany (Montebamboli and Casteani, Italy) has been known since the nineteenth century. Three chelonian species were recognized by Ristori in 1891: Emys depressa, E. campanii, and E. parva. Revision of their type material, together with the study of new fossils from a different but correlated locality, Pian Calcinaio (Scansano), allows one to state that they can be referred to the genus Mauremys and that they belong to one single species. The new combination M. campanii (Ristori, 1891) is here proposed. Phylogenetic analysis indicates that $M$. campanii is closely related to the modern post-Miocene group of Mauremys species and shows a sister-group relationship with the Plio-Pleistocene $M$. gaudryi. The remains of $M$. campanii come from an insular setting which progressively lost its endemic mammal fauna, defined as the Oreopithecus Zone Fauna, enabling us to compare the pattern of survival of the chelonians with that of the mammals. In contrast to the radical turnover suffered by mammals, softshell turtles (Trionyx sp.) and terrapins (M. campanii) are present both in the pre-Messinian V1-V2 and Messinian V3 assemblages. Terrestrial tortoises (Testudo amiatae Pantanelli, 1893, Testudo s.1.) show a different pattern, because they appear only in the V3 assemblage, possibly because they apparently dispersed into Italy as recently as the Messinian. M. campanii represents the southernmost evidence of the genus Mauremys in the uppermost Miocene of Europe, filling a gap in the palaeogeographic and chronological distribution of this genus.
\end{abstract}

\section{INTRODUCTION}

$\mathrm{T}$ HE OCCURRENCE of freshwater turtle remains in the late Miocene lignites of the sedimentary basin of southern Tuscany (localities of Casteani and Montebamboli; Grosseto province; central Italy) was reported by several authors in the second half of the nineteenth century. As already briefly described by Ristori (1891), the remains are represented by several carapaces and plastrons that are mostly incomplete, often highly compressed, and adherent to each other. Skulls, vertebrae, and appendicular bones are generally missing.

The first reports by Rütimeyer (1876) and Weithofer (1888) referred remains, respectively from Montebamboli and Casteani, to the genus Emys Duméril, 1806. It is worth noting that during the nineteenth century, nearly 90 extant species that are now ascribed to the families Chelidae, Chelydridae, Dermatemydidae, Emydidae, Geoemydidae, Kinosternidae, Pelomedusidae, Platysternidae, Podocnemididae, and Testudinidae were included in the genus Emys (Fritz and Havaš, 2007), and consequently it was a common habit for paleontologists to refer to this genus, at least preliminarily, each fossil freshwater turtle that was not trionychoid in appearance. It is therefore not surprising that a few years later than their first mention in the literature, Ristori referred three new species, Emys depressa Ristori, 1891, E. campanii Ristori, 1891, and E. parva Ristori, 1891 to this genus on the basis of a brief description of shell remains from Montebamboli and Casteani. The original definition of these species was further updated and better characterised by the same author in a subsequent and larger monographic work (Ristori, 1895), where he also figured the most significant remains.

Merciai (1907) attributes to Emys sp. an indeterminate shell fragment from Ribolla, near Casteani. Kuhn (1964), reporting the inventory of these remains, proposed for the first time a probable synonymy between E. parva and E. depressa [Emys parva Ristori, 1895 (?=Emys depressa Ristori, 1891)], and then, possibly because of a lapsus calami, changed E. campanii to E. campani (he also considered $E$. parva to have been first described in 1895 and not 1891). After about one century, Guasparri (1992) figured an unpublished fragment attributed by label to E. depressa and suggested that all the Emys remains from Montebamboli and Casteani most probably belong to this species. Recently, Delfino (2002), on the basis of a critical revision of the literature, suggested that $E$. depressa is the sole taxon whose remains are probably representative to justify specific identification, and that the differences within the genus Emys are so striking as to support its taxonomic attribution to a different genus, namely Mauremys Gray, 1869, present in Europe from the late Oligocene to the present (Hervet, 2000, 2004; Lapparent, 2001).

Furthermore, Delfino (2002) described several unpublished shell elements from the same area, Pian Calcinaio, near Scansano (Grosseto province), from the collections of the Naturhistorisches Museum of Basel, Switzerland, and attributed them to Mauremys sp. Despite the antiquity of the literature in which Ristori's proposals occur, the availability of their types, and the presence of new materials coming from the same area, the taxonomy and phylogenetic relationships of the terrapins from the late Miocene of southern Tuscany still have not been assessed with a modern approach.

This paper presents a revision of the type material of the species $E$. depressa, E. campanii, and E. parva, with the description of the Mauremys remains from Pian Calcinaio, as well as with the evaluation of their phylogenetic relationships.

The fact that the material comes from a paleo-archipelago which progressively lost the endemic taxa characteristic of the Oreopithecus Zone Fauna will allow us to compare the pattern of survival of the chelonians with that of the mammals during the late Miocene faunal turnover.

\section{MATERIALS AND METHODS}

The fossil chelonian remains described here come from the late Miocene continental succession of southern Tuscany. The Grosseto area was characterized by some middle- to small-sized fluviolacustrine basins in which were deposited lignitiferous sedimentary successions (Martini and Sagri, 1993), extensively exploited from the late seventeenth to the early nineteenth centuries. A rich collection of late Miocene (Tortonian) fossil vertebrates was recovered at that time, thanks to the careful attention of mine engineers and local paleontologists. These remains (from the Casteani and Montebamboli localities) have historically been stored in the collections of the "Museo Geopaleontologico del Regio Istituto di Studii Superiori" and "Museo dell'Istituto Tecnico" in Florence, as well as in those of the Pisa Museum and "Museo 


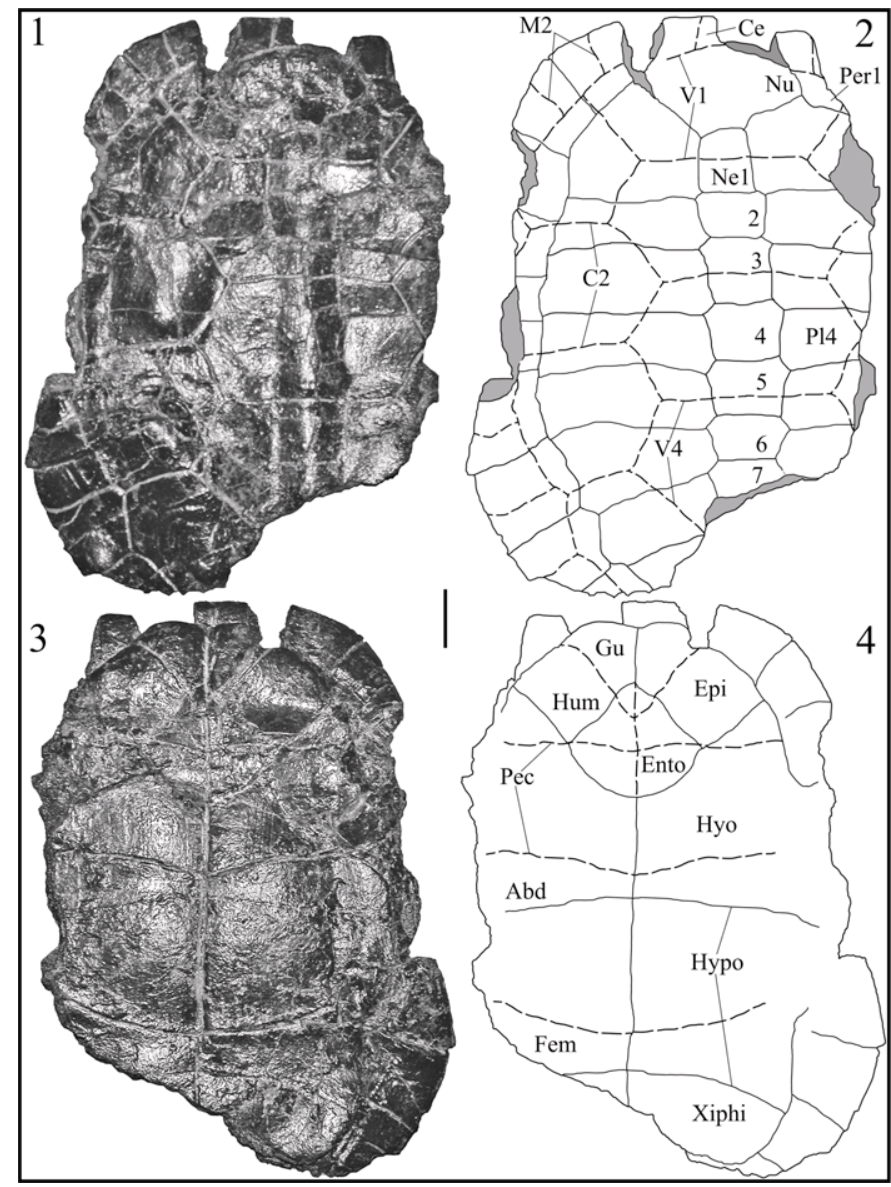

FIGURE 1-Mauremys campanii (Ristori, 1891) n. comb. 1, 3, IGF-11762V, photographs in dorsal and ventral views; 2, 4, interpretative drawings of the same specimen. Continuous line = bony junction; dashed line $=$ scute sulci. Grey areas indicate fragmented surfaces. Abbreviations: Abd, abdominal; C, costal; Ce, cervical; Ento, entoplastron; Epi, epiplastron; Fem, femoral; Gu, gular; Hum, humeral; Hyo, hyoplastron; Hypo, hypoplastron; M, marginal; $\mathrm{Ne}$, neural; Nu, nuchal; Pec, pectoral; Per, peripheral; Pl, pleural; V, vertebral; Xiphi, xiphiplastron. Scale bar $=20 \mathrm{~mm}$.

dei Fisiocritici" in Siena (Ristori, 1891, 1895). Within the frame of this research, we found the remains described and figured by Ristori, along with several unpublished chelonian remains probably not examined by him, in the collections where the materials of the abovementioned institutions were combined: the geo-paleontological collections of the "Museo di Storia Naturale dell'Università" in Florence (formerly known as Istituto di Geologia di Firenze; acronym: IGF), of the "Museo di Storia Naturale dell'Accademia dei Fisiocritici" in Siena (acronym: MSNAFS), of the "Museo di Storia Naturale e del Territorio dell'Università di Pisa" in Pisa-Calci (acronym: MSNTUP), and of the "Museo Geologico dell'Università di Bologna” (acronym: MGUB). In recent years, field surveys in the Baccinello-Cinigiano basin (Grosseto Province; Benvenuti et al., 2001) allowed the recovery of new terrapin material from the Pian Calcinaio locality, now belonging to the Baccinello collection of the Naturhistorisches $\mathrm{Mu}-$ seum of Basel (acronym: NMB-Bac). Catalogue numbers of all the identified terrapin remains from the late Miocene localities of southern Tuscany are reported in Appendix 1.

The morphology of the late Miocene terrapins from southern Tuscany was compared with that of the fossil species of the genus Mauremys (see Hervet, 2000, 2003, 2004). Anatomical nomenclature follows Lapparent (2001), whereas taxonomic nomenclature follows Fritz and Havaš (2007). It is noteworthy that, according to Fritz and Havaš (2007), the genus Mauremys is

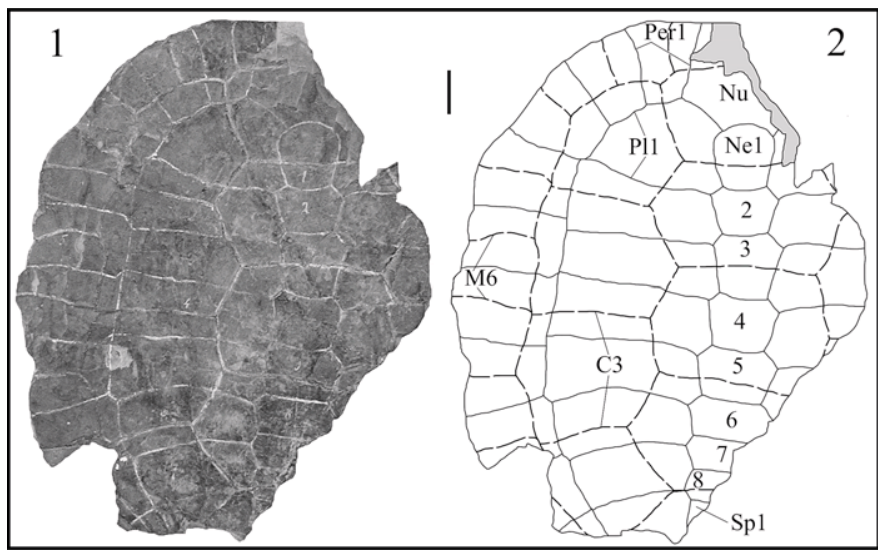

FIGURE 2-M. campanii (Ristori, 1891) n. comb. 1, 2, MSNTUP-I10553, photograph and interpretative drawing of the carapace in dorsal views. Continuous line = bony junction; dashed line = scute sulci. Grey areas indicate fragmented surfaces. Abbreviations: C, costal; Ce, cervical; M, marginal; Ne, neural; $\mathrm{Nu}$, nuchal; Per, peripheral; Pl, pleural; Sp, suprapygal; V, vertebral Scale bar $=20 \mathrm{~mm}$

considered to belong to the family Geoemydidae, an opinion supported by molecular and morphological studies (Gaffney and Meylan, 1988; Spinks et al., 2004; Krenz et al., 2005).

The phylogenetic analysis was based on a data matrix of 54 discrete morphological characters (see Hervet, 2003, for list of characters and matrix), which was subjected to a maximum parsimony analysis using PAUP* 4.10b (Swofford, 2002). The analysis included 31 ingroup taxa and two outgroups (Platysternon megacephalum [Gray, 1831], and Elkemys australis [Yeh, 1974]). The character coding of $M$. campanii is reported in Appendix 2 along with that of $M$. portisii. The latter was modified from Hervet (2003), after direct observation of the holotype by the first author; the minor variations of character state are shown in bold font. Previous analysis with this matrix was executed with Hennig86 operated from Winclada by Hervet (2003), whereas the present analysis was executed with PAUP* $4.0 \mathrm{~b} 10$ using the PAUP command "hsearch swap=tbr" corresponding to the Hennig86 command " $m h^{*}$ bb*" used by Hervet (2003). Multistate characters were left unordered. Following Hervet (2003), all the characters were equally weighted 1 , with the exception of character 0 which had a weight of 2 . Abbreviations used in the text: $\mathbf{A b d}=$ abdominal; $\mathbf{A n}=$ anal; $\mathbf{C}=\operatorname{costal} ; \mathbf{C e}=$ cervical; $\mathbf{C e L}$ $=$ cervical length $; \mathbf{C e W}=$ cervical width; Ento $=$ entoplastron; EntoL = entoplastron length; Epi = epiplastron; Fem = femoral; $\mathbf{G u}=$ gular; $\mathbf{G u L}=$ gular length; $\mathbf{G u W}=$ gular width; Hum $=$ humeral; HumL = humeral length; Hyo = hyoplastron; Hypo = hypoplastron; $\mathbf{M}=$ marginal; $\mathbf{M N}=$ Mammal Neogene zone; $\mathbf{N e}=$ neural; $\mathbf{N u}=$ nuchal; $\mathbf{N u L}=$ nuchal length; NuW $=$ nuchal width; $\mathbf{P e r}=$ peripheral; $\mathbf{P e c}=$ pectoral; $\mathbf{P e c L}=$ pectoral length; PI = pleural; Pyg = pygal; $\mathbf{S p}=$ suprapygal; $\mathbf{V}=$ vertebral; Xiphi $=$ xiphiplastron.

\section{SYSTEMATIC PALAEONTOLOGY}

Class REPTILIA Laurenti, 1768

Order TESTUDINES Batsch, 1788

Family GEOEMYDIDAE Theobald, 1868

Genus MAuremys Gray, 1869

MAUREMYS CAMPANII (Ristori, 1891) new combination Figs. 1.1-4, 2.1, 2.2, 3.1-6, 4.1-3, Table 1

Emys sp. RÜTIMEYeR, 1876, p. 44; WeITHOFER, 1888, p. 363; MerciaI, 1907, p. 86, pl. 4, fig. 8.

Emys depressa RISTORI, 1891, p. 307; RISTORI, 1895, p. 41, pl. 2, 5, 6, figs. 14, 15, 24, 25, 26, 31; KuHN, 1964, p. 79; GuAsPARRI, 1992, p. 57, fig. 32; Delfino, 2002, p. 180, fig. 8. 


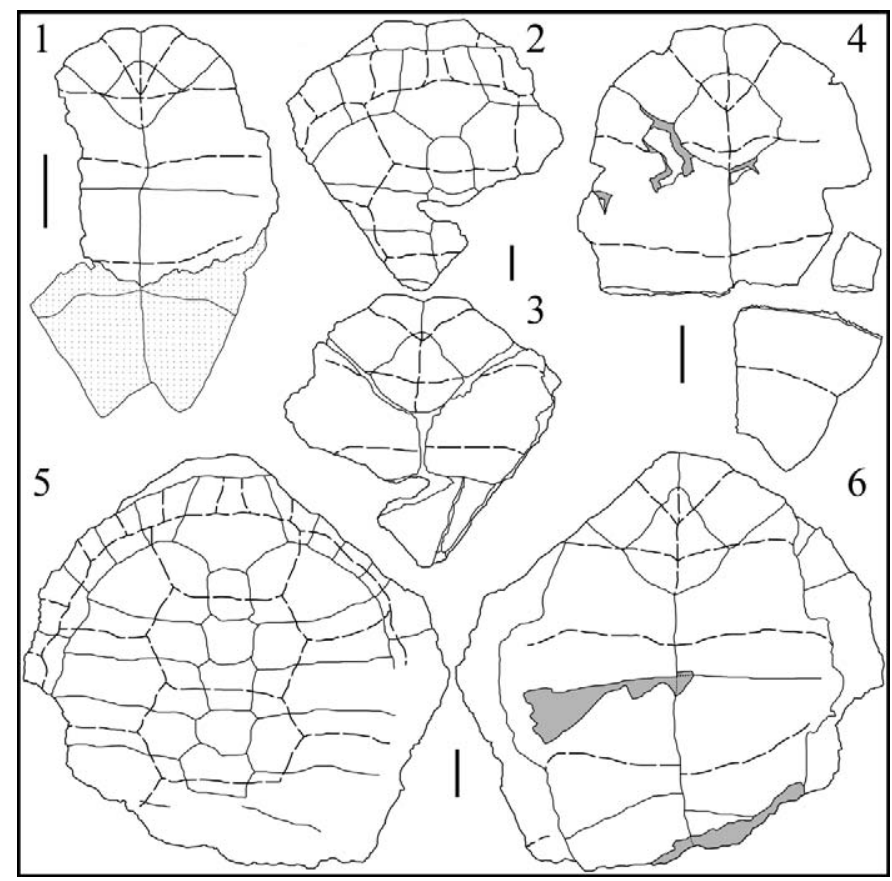

FIGURE 3-M. campanii (Ristori, 1891) n. comb. 1, IGF-4099V, interpretative drawings of the plastron in ventral view; 2, 3, IGF-11759V, interpretative drawings in dorsal and ventral views (in dorsal view, the anterior border of the epiplastra, their medial bony sutures and the visceral fold of gular sulci are visible); 4, NMB-Bac-1229, interpretative drawings of the plastron in ventral view; 5, 6, IGF-11761V, interpretative drawings in dorsal and ventral views. Continuous line $=$ bony junction; dashed line $=$ scute sulci. Grey areas indicate fragmented surfaces, pointed area indicates countermark of the visceral plastral surface. Scale bar $=20 \mathrm{~mm}$.
Emys campanii RISTORI, 1891, p. 307; RISTORI, 1895, p. 64, pl. 4, 6, figs. 18, 20, 21, 22, 28, 29; Delfino, 2002, p. 180.

Emys parva RISTORI, 1891, p. 307; RISTORI, 1895, p. 78, pl. 3, 4, 6, figs. 16, 17, 19, 23, 30; Kunn, 1964, p. 84; Delfino, 2002, p. 180.

Emys campani Roger, 1902, p. 50, 51; KUHN, 1964, p. 78

Mauremys sp. Delfino, 2002, p. 91, pl. 18, figs. C-M, pl. 19, figs. A-C; CHESI ET AL., 2007, p. 293.

Geoemydinei indet. Delfino, 2002, p. 181.

Referred material.-Altogether, 27 diagnostic remains and fragments have been referred to $M$. campanii. A further 38 nondiagnostic remains have been tentatively referred to this taxon. A complete list is provided in Appendix 1.

Occurrence.-All the localities are late Miocene in age (among others, see Delfino and Rook, 2008, and literature therein): Casteani, Montebamboli, Pian Calcinaio (Grosseto province, Italy). Casteani and Montebamboli are pre-Messinian (MN12), whereas Pian Calcinaio is Messinian in age (MN13). Casteani is referred to the local assemblage V1, Montebamboli to the slightly younger V2, and Pian Calcinaio to V3 (see below the section "The latest Miocene Tusco-Sardinian area").

Emended diagnosis.-This species differs from all other fossil or extant Mauremys species in the following combination of characters: Ce longer than wider; $\mathrm{Ce} / \mathrm{Nu}$ length ratio greater than $30 \%$; V1 larger than $\mathrm{Nu}$ (width ratio more than 130\%) and nearly reaching the Per1-2 sutures; V1 much wider than long (V1W/V1L > 1,7); wide contact V1-M2; the advancement of the anterior marginals on pleurals, with M1 reaching the nuchal extremities and M2 located near Pl1; reduced axillary and inguinal notches; reduced axillary processes, just reaching the extremity of Pl1; neural series posteriorly irregular; irregular pleuro-peripheral correspondence in the posterior region of the carapace; contact $\mathrm{C} 3-$ M6 very restricted; presence of a large axillary shield; absence of contact V5-M10; V5-M12 sulci on Pyg or on both Sp2 and Pyg; Sp2 hexagonally shaped, with straight antero-lateral and postero-lateral sides and sub-equal in length; Pyg relatively larger than long; weak, V-shaped cranial notch of Epi; Gu usually longer

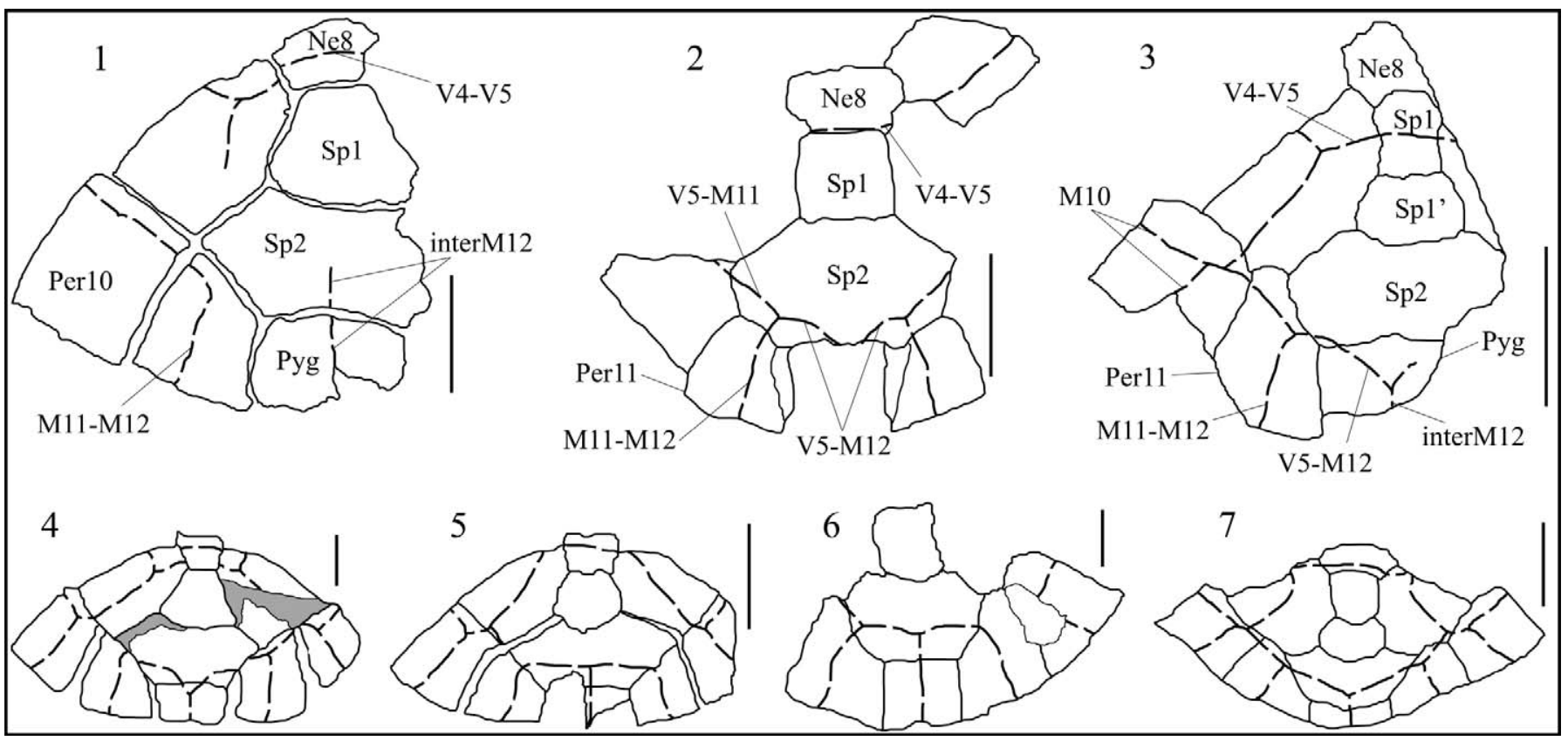

FigURE 4-Comparison among the posterior carapacial area of some geoemydid taxa. 1-3, M. campanii (respectively, IGF-4110V, NMB-Bac-1229, MSNTUP-I10556-partim); 4, Palaeochelys bussenensis (modified from Hervet and Lapparent, 2000, fig. 2B); 5, Palaeomauremys mlynarskii (modified from Hervet and Lapparent, 2000, fig. 2A); 6, Mauremys sarmatica (interpretative drawing from Hervet, 2004, pl. 10, fig. H); 7, Mauremys leprosa (interpretative drawing from Hervet, 2000). Continuous line = bony junction; dashed line = scute sulci. Abbreviations: M, marginal; Ne, neural; Per, peripheral; Pyg, pygal; Sp, suprapygal; V, vertebral. Scale bar $=20 \mathrm{~mm}$. 


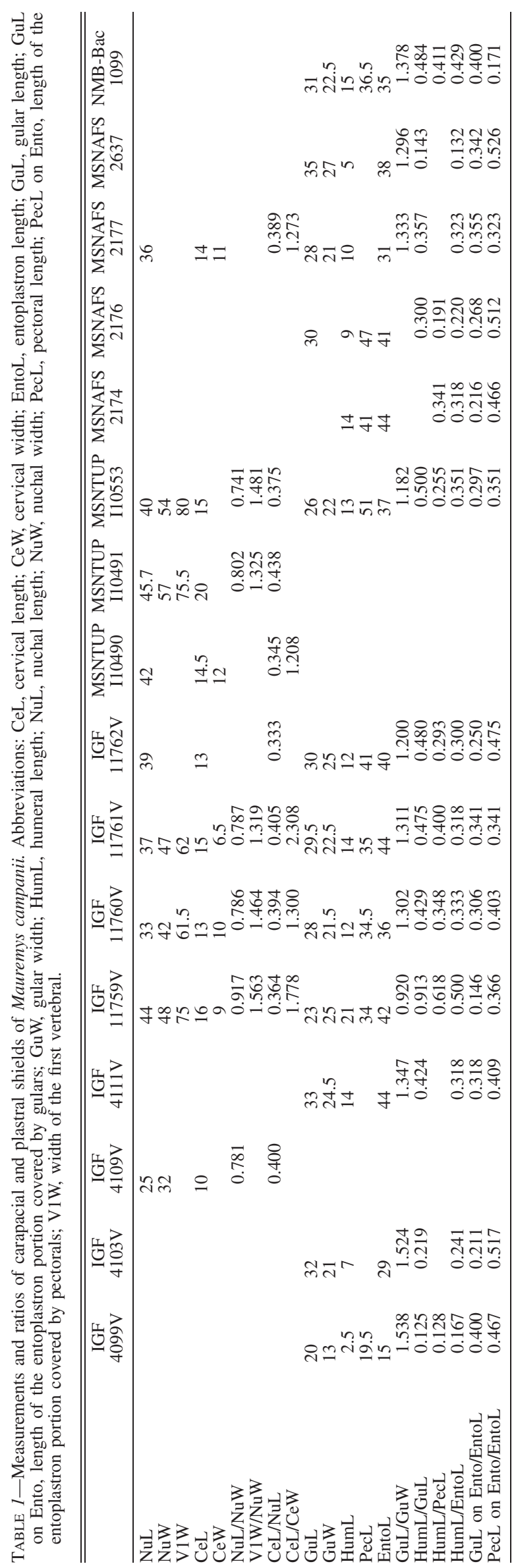

than wide (but becoming less so late in ontogeny); Pec reaching Epi with the Hum-Pec sulcus and covering from one third to one half of Ento.

Preservation.-Most of the chelonian remains from the lignites of southern Tuscany are deformed and so dorsoventrally compressed that often carapacial and plastral elements are forced together into one single piece. Most of the reconstructed specimens are the result of the restoration of several fragments formerly held in the lignites. Some fragments have suffered recent damage when compared to the descriptions and drawings published by Ristori (1891, 1895).

Description.-The following description deals only with the most representative features, whose status has been assessed on the entire sample of remains published by Ristori or identified by label by Ristori and the curators of the collections as E. depressa, E. campanii, E. parva, Emys sp., Testudo sp., and Trionyx sp.

Carapace (Figs. 1.1, 1.3, 2.1, 2.2, 3.2, 3.5, 4.1-3).-The external outline of the carapace is not preserved in any Tuscan remains.

The nuchal $(\mathrm{Nu})$ is hexagonal, with the upper and upper-lateral sides wider than, respectively, the lower and the lower-lateral ones. Near the external border, the cervical scute sulci $(\mathrm{Ce})$ are always present on the dorsal surfaces of the nuchal. The cervical shape is slightly trapezoidal, longer than wide, with the short side forming part of the external border of the shell (Fig. 3.2, 3.5). The ventral underlap of the cervical is perceivable only in MSNTUP-I10490 and MSNAFS-2177, and is slightly longer than Ce. Both surfaces of the nuchal also present sub-horizontal scute sulci that encounter Ce: the V1-M1 sulci on the dorsal surface, the M1-M1 sulci on the visceral one. The $\mathrm{Ce} / \mathrm{Nu}$ length ratio varies between 0,333 (in IGF-11762V) and 0,438 (in MSNTUPI10491) (see CeL/NuL in Table 1).

The first vertebral, $\mathrm{V} 1$, is much wider than $\mathrm{Nu}$, and in contact with $\mathrm{Ce}$ and both $\mathrm{M} 1-2$. The $\mathrm{V} 1 / \mathrm{Nu}$ width ratio goes from 1.319 (in IGF-11761V) to 1.563 (in IGF-11759V) (see V1W/NuW in Table 1). V1 partially covers $\mathrm{Ne} 1$, both Pl1 and Per1, almost reaching the sutures between the Per1 and Per2 as shown by MSNTUP-I10553 and by IGF-11762V (Fig. 1.2).

The first neural plate, Ne1, is vaguely ovoid, with the anterior side rounded, and is traversed by the V1-V2 sulcus. N2-5 are hexagonal, with the anterolateral sides shorter than the posterolateral ones. There is no evidence of the presence of metaneurals. Towards the caudal region, the neural series becomes quite irregular and the neural plates are wider and shorter than the anterior ones. V2-V3 sulcus crosses Ne3, V3-V4 crosses Ne5, and V4-V5 crosses Ne8.

The first four vertebral shields, V1-4, seem to have the same width. V5 appears to be narrower than the others, and is not in contact with M10 (Fig. 4.3).

The first pleural plate, Pl1, is anterolaterally rounded, in contact with Per1-3, P12, Nu, Ne1-2, and covered by V1, V2, and $\mathrm{C} 1$. Pleural plates P12-8, have nearly rectangular and caudally narrowing shapes. $\mathrm{Pl} 3$ is the widest. The costals are narrower than the vertebrals. C3 is in contact with M6.

Only a few specimens included peripheral plates, usually the anterior ones. In dorsal view, the costo-marginal sulci are centrally located, while the inter-marginal sulci seem to curve anteriorly near the external border of the peripherals. In NMB-Bac1229 , both Per3 are present: they are provided with a wide sutural surface to join the plastron and show a well-developed axillary shield and the presence of musk pores. A comparatively good pleuro-peripheral correspondence is shown by the anterior region of the carapace (only Per3-Pl1). The elements of the caudal region of the carapace are preserved in few specimens (IGF-4108V, IGF4110V, MSNTUP-I10487, MSNTUP-I10556-partim, NMB-Bac1229), but they are adequate to assess the main features of this area of the shell. The posterior region of the carapace shows small gaps between plates, suggesting an imperfect pleuro-peripheral correspondence. 
Posterior to the last neural plate (Ne8), two suprapygals and a pygal plate are present (Fig. 4.1-3). The first suprapygal, Sp1, is narrow and long, completely covered by V5 except in NMB-Bac1229 and MSNTUP-I10556 (partim), and laterally in contact with P18 pairs. Its shape varies from ovoid in IGF-4108V to trapezoidal in IGF-4110V. The second suprapygal, Sp2, is a wide hexagon, with the anterior edge in contact with Sp1, the lateral ones with P18 and Per11, and the posterior one with Pyg. Sp2 is shorter than Sp1 and narrower than V5. V5-M12 and M12-M12 sulci are present on Sp2. In NMB-Bac-1229 (Fig. 4.2), Sp2 is also partially covered by M11: both Per11 show only M11-M12 sulcus, while the M11-V5 sulci are present on Sp2. In MSNTUP-I10556 (partim), two bony elements are present between Ne8 and Sp2, probably from the splitting of Sp1 (Fig. 4.3). In this specimen, Ne8, $\mathrm{Sp} 1$ and Sp2 plates show traces of a crest or keel.

In three out of five cases, the V4-V5 sulcus is not present on Ne8: in IGF-4108V it occurs on Sp1 (near the Ne8-SP1) sutures, in NMB-Bac-1229 in correspondence of the Ne8-Sp1 sutures, whereas crosses Sp1 in MSNTUP-I10556 (partim) (Fig. 4.2, 4.3).

The pygal plate, Pyg, is rectangular, slightly wider than long. In three cases (IGF-4108V, IGF-4110V [Fig. 4.1], MSNTUPI10487), only the interM12 sulcus seems to be present on Pyg. Probably due to a posterior displacement of the caudal horny shields, Pyg is partially covered also by V5 in MSNTUP-I10556 (partim) and probably in NMB-Bac-1229. In some remains, growth annuli are evident on the dorsal surfaces of the carapace, especially in IGF-I11759.

Plastron (Figs. 1.5, 1.6, 2.1, 2.3, 2.5).-The plastron is longer than wide, rounded at its edges, and apparently is as long as the carapace. Due to the vertical compression of the shells, in most fossil specimens the plastral portion of the axillary and inguinal notches is broken, lost or not well visible.

The anterior plastral lobe appears to have a trapezoidal shape. The epiplastra, Epi, are long and narrow, with a rounded anterior border. A shallow, wide V-shaped cranial notch is present, and the epiplastral width shows a modest constriction at the level of the gular sulci. The posteromedial parts of the epiplastra, in contact with Ento, show a proximal concavity that distally usually becomes a convexity. In visceral view, the epiplastral lips are slightly wider than the gulars and not cranio-caudally expanded. In cranial view, the area corresponding to the gular shields $(\mathrm{Gu})$ forms a distinct dorsal concavity and ventral convexity. In ventral view, the area covered by $\mathrm{Gu}$ is vaguely heart-shaped and slightly protruding out of the anterior outline of the plastron lobe. EpiHyo sutures are anteriorly well-directed and slightly sinuous.

The entoplastron, Ento, is pyriform, often wider than longer. The anterior sides are sinuous, medially convex, and distally concave, while the posterior ones are convex. Ento is partially covered by gulars $(\mathrm{Gu})$ anteriorly, humerals (Hum) centrally and pectorals (Pec) posteriorly (Fig. 1.4). The gular shape changes ontogenetically: in the small individual IGF-4099V Gu are longer than wide (length/width ratio of each gular $=1.538$ ) but become slightly wider than long in a bigger and presumably older individual as IGF-11759V (length/width ratio = 0.932) (see GuL/ $\mathrm{GuW}$ in Table 1). Also the encroachment of the anterior plastral shields onto Ento changes with growth: Gu covers $42 \%$ of Ento in a sub-adult (IGF-4099V), 25-35\% in adults, but only about $15 \%$ in an old individual (IGF-11759V) (see GuL on Ento/EntoL values in Table 1). Hum are very short in relation to entoplastral length (EntoL), whereas during growth they become proportionally longer in respect to $\mathrm{Gu}$ : Hum/Ento and Hum/Gu length ratios run respectively from 0.169 and 0.125 (in IGF-4099V) to 0.500 and 0.913 (in IGF-11759V). The entoplastral portion is overlapped by the pectorals (PecL on Ento/EntoL) to a decreasing degree in respect of $\mathrm{Gu}$ : Pec cover $55 \%$ of the entoplastral length in a sub-adult, but just $30-50 \%$ in adults: the pectoral length seems not to change much during growth; so much as instead Hum and Gu do: the changing ratios reflect changes in Hum and
Gu. The humeral-pectoral sulcus (Hum-Pec) nearly or completely traverses the posteromedial corner of both Epi, mostly the left one (Figs. 1.6, 2.1, 2.3, 2.5).

The hyoplastra, Hyo, are very short, usually shorter than Ento and Hypo. The pectoral-abdominal sulcus (Pec-Abd) crosses Hyo in their caudal half. The hyoplastral branch of the axillary buttress is clearly preserved only in NMB-Bac-1229, showing the presence of a large axillary shield, while the bridge portion is perceivable in IGF-11761V and seems to be reached by Pec-Abd sulcus (Fig. 3.5).

The abdominals, Abd, are the longest of the plastral shields: one third of the length covers the Hyo and two thirds the Hypo.

The hypoplastra, Hypo, are long and participate in the inguinal buttresses. The sulcus corresponding to the abdominal-femoral junction (Abd-Fem) is V-shaped; it crosses Hypo and reaches the inguinal notch (Fig. 1.4). The bad preservation of the lateral portion does not permit determination of the presence of the inguinal shield, or the extension of the contact between the hypoplastral branch of the inguinal buttress and the correspondent pleurals. The xiphiplastra, Xiphi, are connected anteriorly to Hypo with near-horizontal or slightly oblique sutural lines. The distal borders of Xiphi show a more or less slight angle corresponding to the femoral-anal sulcus (Fem-An), which crosses Xiphi nearly perpendicular to the lateral edge of the bone (MSNTUP-I10556, NMB-Bac-1229; see Fig. 3.4). A deep, wide anal notch is medially present, and each posterolateral process has a tip slightly bent ventrally and dorsally thickened.

In IGF-4099V, the xiphiplastral countermark, left on the sediment, shows semi-circular convexities, corresponding to concavities of the visceral surfaces probably due to muscular insertions.

The absence of a complete plastron does not permit assessment of the full plastral formula, including the ratio relationship between Hum and An, and between Pec and Fem. The partial plastral formula is $\mathrm{Abd}>\mathrm{Pec}>\mathrm{Gu}>\mathrm{Hum}$, while Fem $>\mathrm{An}$.

\section{RESULTS AND DISCUSSION}

The type material of the species Emys campanii, E. depressa, and E. parva, from Casteani and Montebamboli, as well as the form from Pian Calcinaio previously referred to as Mauremys sp., share the same morphological features and consequently belong to the same taxon. All the characters discussed here are referable to the adult condition, there being no evidence of open carapacial and plastral fontanelles: the high number of growth annuli suggests that IGF$11759 \mathrm{~V}$ is an old individual, whereas, judging by its small size (it is the smallest specimen), IGF-4099V is probably a sub-adult.

The absence of inframarginals and infragulars, the shape of the nuchal (with its short anterior side), the bony link between carapace and plastron, the posterior reduction of the epiplastra, and the anteriorly directed epi-hyoplastral sutures, represent apomorphic features permitting the attribution of the taxon to the superfamily Testudinoidea. Among several features, the referral to the family Geoemydidae is clearly supported by the presence of musk pores, a character listed by Hirayama (1985) as a true geoemydid synapomorphy. The absence of the typical ptychogasterid spikes in the epiplastra, and the presence of a regularly hexagonal neural series represent two plesiomorphic features, characteristic of the "Palaeochelys s.l.-Mauremys" lineage (see Hervet, 2003).

Taxonomic remarks.-As for the name of this species, it should be taken into consideration that Ristori (1891) described three new species from the material coming from southern Tuscany: $E$. depressa, E. campanii, and E. parva. The species Emys depressa was originally named by Merrem in 1820 (now Phrynops geoffroanus [Schweigger, 1812]; see Fritz and Havaš, 2007), about 70 years before Ristori, and, therefore, according to Article 57.2 of the ICZN (1999) the species name Emys depressa Ristori, 1891 is a nomen invalidum, being a junior primary homonym.

Acting as first reviewers, we chose the name Emys campanii for the Mauremys from Southern Tuscany, and therefore we name the 


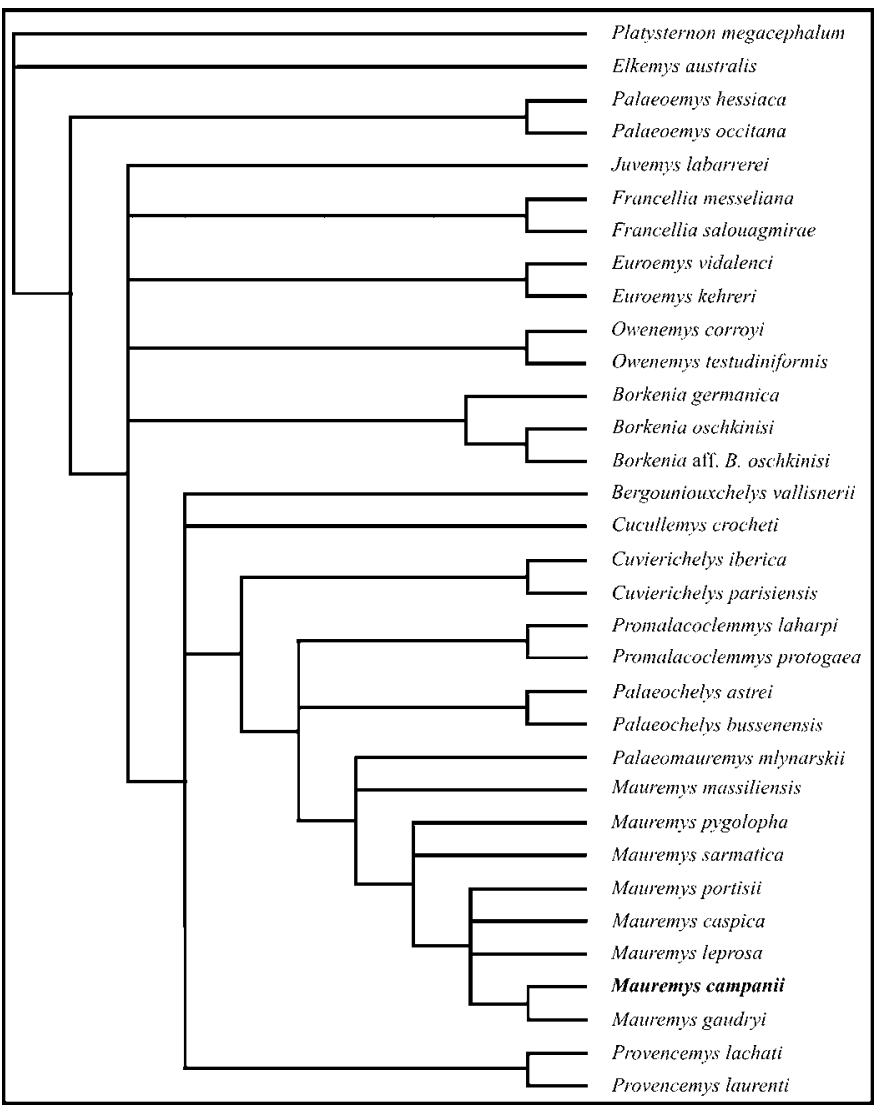

FIGURE 5-Strict consensus of 792 equally optimal trees (length $=170$ consistency index excluding uninformative characters $=0.500$, retention index $=0.780$ ); maximum parsimony analysis, 31 ingroup taxa, 54 discrete morphological characters (see Appendix 2). Noteworthy is that Palaeomauremys mlynarskii clusters with all the Mauremys species (the possible reasons of such grouping have been already discussed by Hervet, 2003), and that $M$. portisii is located in a politomy comprising also the extant taxa and the clade M. gaudryi-M. campanii.

material coming from Montebamboli, Casteani, and Pian Calcinaio Mauremys campanii (Ristori, 1891) new combination. Emys parva Ristori, 1891 becomes a subjective synonym of this species.

Phylogenetic analysis.-The phylogenetic analysis recovered 792 equally optimal trees (length $=170$, consistency index excluding uninformative characters $=0.500$, retention index $=0.780$ ). The strict consensus of these trees is consistent with the previous analyses using this matrix (Fig. 5). The analysis of the character coding of $M$. campanii clearly places the Tuscan terrapin material within the genus Mauremys because of the presence of the following unambiguous apomorphic features: reduced axillary and inguinal notches (character 3, state 1; homoplasic), vertebral series regularly enlarged, with $\mathrm{V} 4 \mathrm{~W}>\mathrm{V} 3 \mathrm{~W}>\mathrm{V} 2 \mathrm{~W}$ and $\mathrm{V} 3 \mathrm{~W} / \mathrm{C} 2-3 \mathrm{~W}>80 \%$ (character 10 , state 1 ; homoplasic), gularo-humeral sulci length relatively larger than gular width, i.e., Gu-HumL/GuW > 0,3 (character 30, state 2; homoplasic); humerals relatively shorter than pectorals, i.e., HumL/ PecL $<70 \%$ (character 39, state 1; not homoplasic), gulars longer than humerals (character 40, state 1; not homoplasic), entoplastron relatively longer than humerals (character 41 , state 1 ; not homoplasic), with a clearly pyriform shape (character 43 , state 2 ; not homoplasic), and finally the narrow, deep anal notch (character 52, state 1; not homoplasic).

Four apomorphic but homoplasic characters group $M$. campanii together with the post-Miocene species: the reduced axillary process, which just reach the extremity of Pl1 (character 1, state 4; unambiguous), the large contact between V1 and M2 (character
7 , state 1 ; unambiguous), the long covering of $\mathrm{Ce}$ on $\mathrm{Nu}$ (character 12, state 1; ambiguous), and the irregular pleuro-peripheral correspondence in the posterior region of the carapace (character 16 , state 1 ; unambiguous).

The sister group relationship between $M$. campanii and $M$. gaudryi is supported by the sharing of three unambiguous, apomorphic but homoplasic features of the anterior region of the carapace: V1 larger than $\mathrm{Nu}$ and nearly reaching the Per1-2 sutures (character 5, state 2); V1 greatly larger than long (character 6, state 2); M1-M2 sulci sometimes located almost in correspondence of Nu-Per1 sutures and M2-C1 near Per1-P11 ones (character 18, state 1) (Fig. 5).

Finally, the hexagonal shape of Sp2 with straight antero-lateral and postero-lateral sides and sub-equal in length (character 25, state 2; unambiguous, homoplasic), and a relatively short, wide pygal (character 26, state 1 unambiguous, homoplasic), distinguish the Tuscan species from $M$. gaudryi, and clearly represent the legacy of its Miocene ancestors.

Morphological comparisons. - In this section, the morphology of $M$. campanii will be discussed in comparison with the known fossil and extant species of the genus Mauremys. The cervical is longer than wide in $M$. campanii $(\mathrm{CeL} / \mathrm{CeW}=1.208<x<2.308$; see $\mathrm{CeL} / \mathrm{CeW}$ in Table 1). According to the results of Lapparent and Van Dijk (1999) and of Hervet (2003), the cervical is wider than long in $M$. caspica $(\mathrm{CeL} / \mathrm{CeW}=0.737<x<0.984$; see Hervet, 2003) and in all other fossil Mauremys species, and longer than wide in $M$. leprosa $(1.10<x<2.468$; see Hervet, 2003).

The ratio between the length of the cervical and the length of the nuchal $(\mathrm{CeL} / \mathrm{NuL})$ clearly shows that $M$. campanii fits only with the post-Messinian Mauremys species. In fact, in M. campanii it varies between 0.333 (in IGF-11762V) and 0.438 (in MSNTUP-I10491) (Table 1), similar to the morphological intervals of the fossil $M$. gaudryi (0.356) and of the extant M. leprosa $(0.290<x<0.471)$ and $M$. caspica $(0.265<x<0.423)$, whereas in the Miocene species $M$. sarmatica and $M$. pygolopha the cervical length is less than $30 \%$ of the nuchal length (Hervet, 2003, 2004).

The first vertebral possesses interesting features that clearly links $M$. campanii with $M$. gaudryi: the relationship between its width and that of the nuchal $(\mathrm{V} 1 \mathrm{~W} / \mathrm{NuW})$, the extension of the contact with M2, and its position in respect of the Per1-2 suture. The first vertebral is wide as the nuchal in M. massiliensis (Oligocene, France) and $M$. pygolopha, and becomes wider in $M$. sarmatica (and M. 'sophiae') and in more derived species (Peters, 1868; Purschke, 1885; Ammon, 1911; Bergounioux, 1936; Hervet, 2004). Together with $M$. gaudryi, the Tuscan remains present the highest range of the $\mathrm{V} 1 / \mathrm{Nu}$ width ratio: it is at least more than 1.3, reaching the highest value of 1.563 in IGF-11759V (see Table 1), very similar to the value of 1.543 attested in $M$. gaudryi (Hervet, 2003). Correlated to this feature, the presence of a wide contact between V1 and M2 is attested in fact only in $M$. sarmatica and in more crownward taxa (Hervet, 2004), but usually this contact is placed far from the Per1-2 suture, with the exception of M. campanii and M. gaudryi, in which the V1-M2 junction nearly traverses the Per1-2 suture.

Among the "Palaeochelys sensu lato-Mauremys" group (Hervet, 2004), the contemporary presence of V1 wider than $\mathrm{Nu}$ and in contact with M2 is also recognized in the species of Promalacoclemmys Reinach, 1900, from the late Oligocene of Switzerland and the early Miocene of Germany (Meyer, 1852; Pictet and Humbert, 1856; Reinach, 1900). A singular exception is represented by Mauremys portisii, an early Pliocene form: it presents a lyre-shaped V1, as large as $\mathrm{Nu}$, similar to that visible in member of Eocene genera Owenemys Hervet, 2004, and Euroemys Hervet, 2004, but in contact with M2 only at its distal corner (Sacco, 1889).

The contact between C3 and M6 is also present in M. sarmatica, M. portisii and in the extant Mauremys species, while the 
absence of V5-M10 contact distinguishes $M$. campanii from $M$. pygolopha, the only Mauremys species possessing this contact.

Hervet (2004), in the phylogenetic reconstruction of the fossil record of the "Palaeochelys sensu lato-Mauremys" group, defined the node P5 constituted by the genera Palaeomauremys Hervet, 2004, and Mauremys, on the basis of the presence of three homoplasic characters, among them the posterior sulcus of V5 on SP2, that is the partial covering of Sp2 by V5 (and the related presence of only the sulcus M12-M12 on the pygal). This last feature was also listed by Lapparent and Van Dijk (1999) as clearly distinguishing the genus Mauremys from the other geoemydid taxa. In M. campanii, this character varies rather widely: $\mathrm{Sp} 2$ is also partially covered by M11 in NMB-Bac-1229, while Pyg is partially covered also by V5 in MSNTUP-I10556 (partim) and in NMB-Bac-1229 (Fig. 4.2, 4.3). The presence of the V5-M12 sulcus on Pyg was already known in Promalacoclemmys and Palaeochelys (Fig. 4.4), grouped by Hervet (2004) at node P4, but not yet in Mauremys. Therefore, the presence of the V5 sulcus on SP2 cannot be included in the character series to define the grouping of genera Palaeomauremys and $\mathrm{Mau}$ remys (node P5 of Hervet, 2004), or to be listed as a diagnostic character of genus Mauremys (Lapparent and Van Dijk, 1999). Although Kotsakis and Mori (1981) identified a shell fragment from the late Miocene of Santa Vittoria d'Alba, already showing V5 on SP2, this feature is uniformly present in Mauremys only since the early Pliocene (M. portisii and M. gaudryi), and then in the extant species (Fig. 4.4-6).

The plastron offers most of the distinguishing characters of $M$. campanii. The entoplastron shape is clearly pyriform, with sinuous anterior sides and convex posterior ones. The gulars extensively encroach upon the entoplastron, more in length than in width, as seen in the genus Mauremys: each gular is usually longer than wide $(0.920<\mathrm{GuL} / \mathrm{GuW}<1.524$; Table 1$)$, approaching $M$. campanii to $M$. massiliensis (1.073 $<x<1.404), M$. gaudryi (1.485), M. portisii (1.188), and the extant M. leprosa $(0.913<x<1.452)$, M. caspica $(0.908<x<1.563)$, but spacing it out from the other Miocene species, as M. pygolopha $(1.467$ $<x<1.869)$, and M. sarmatica $(1.304<x<1.657)$, which show a higher values interval for this feature (Hervet, 2003).

The length relationships among the anterior plastral shields, i.e., $\mathrm{Gu}, \mathrm{Hum}$, and Pec, and between them and Ento, approach the Tuscan remains to $M$. gaudryi and $M$. leprosa: $M$. campanii shows a range of values of HumL/EntoL $(0.132<x<0.5)$ similar to that of $M$. leprosa $(0.164<x<0.586)$ and $M$. gaudryi $(0.352)$, near to $M$. sarmatica $(0.3<x<0.481)$, but different from those of $M$. caspica $(0.428<x<0.704)$, M. massiliensis $(0.538<x<0.637), M$. pygolopha $(0.3<x<0.646)$, and $M$. portisii $(0.613)$. Therefore, in relation to the covering of Ento in $M$. campanii, during the growth Hum and Pec apparently increase in length to the detriment of $\mathrm{Gu}$, whereas in M. leprosa the highest growth rate is shown by Pec and in $M$. caspica. In fact, in the sub-adult IGF-4099V (Fig. 3.1) Hum covered about $17 \%$ of Ento, Gu covered $40 \%$, whereas in adults Hum overlapped up to $50 \%$ of the entoplastron surface, and $\mathrm{Gu}$ covering decreased to $15-30 \%$ (see Table 1). Instead, data from Hervet (2003) suggest different growth patterns among the anterior plastral shields in the extant $M$. leprosa and $M$. caspica: with the increasing of EntoL, in the Iberian species the covering by Pec increases from $15 \%$ to $49 \%$ of EntoL, whereas Hum overlapping seems to decrease from about $50 \%$ to $30 \%$ and Gu covers $25-40 \%$ of the entoplastron surface; otherwise, in the Caspian species, the anterior plastral shields linearly follow the growth of the entoplastron, thus stabilising the extension of covering: Hum around 55\%, Gu 20\%, and Pec 25\%.

The position of Hum-Pec sulcus in $M$. campanii is the most anterior among the fossil and extant Mauremys, reaching the posterior corner of Epi and crossing Ento at its midline in nearly all the Tuscan samples. The very anterior position of the humeralpectoral sulci (character 49, state 4), is also common to M. sarmatica, M. gaudryi, M. caspica and M. leprosa, but not reaching

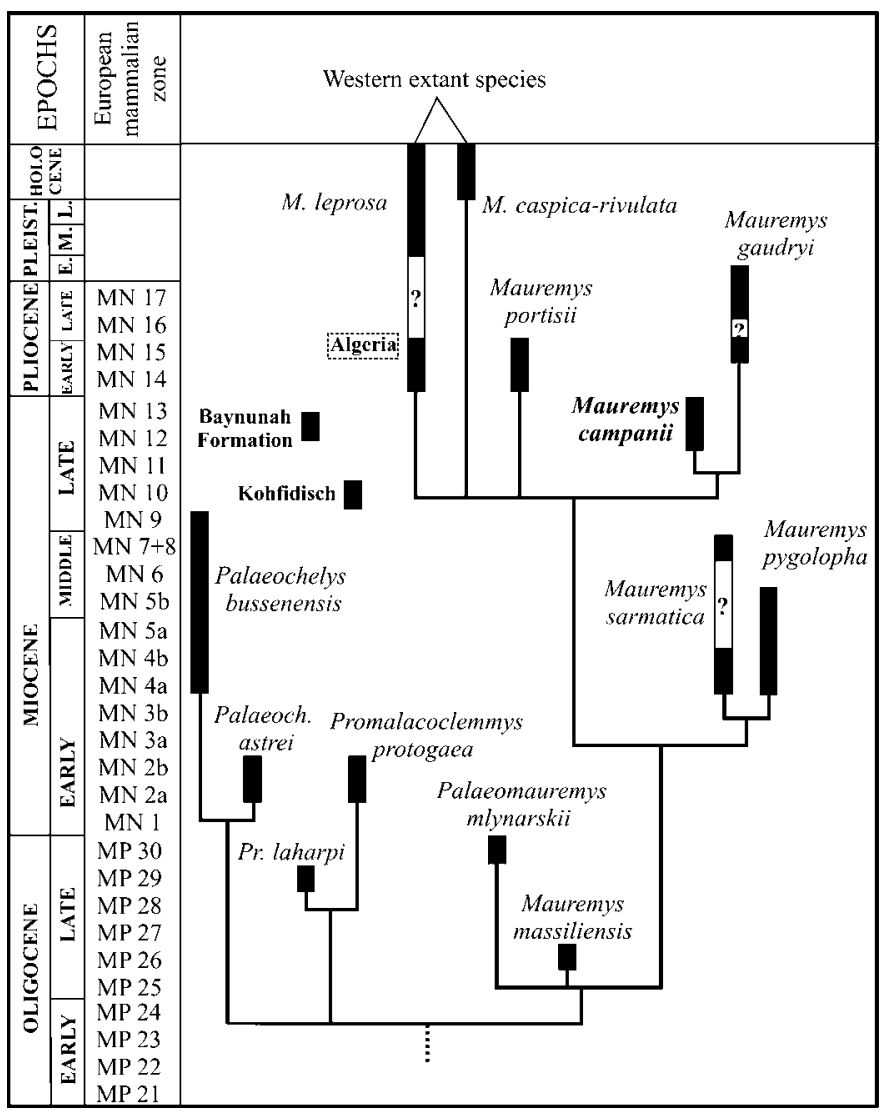

FIgURE 6-Stratocladogram of genera Palaeochelys, Promalacoclemmys, Palaeomauremys and Mauremys, from the strict consensus analysis. Absence of remains in the fossil record is indicated by "??".

the postero-medial corner of the epiplastron: $M$. campanii show the most anterior position of the Hum-Pec sulci, otherwise confirmed by the highest values of the entoplastron surface covered by Pec. In $M$. campanii, the entoplastral portion covered by pectoral (PecL on Ento/EntoL; see Table 1) varies from 33\% to 53\%, differing from M. massiliensis (only 16\%), M. sarmatica $(20 \%)$ or extant $M$. rivulata $(28 \%)$.

The poor preservation of the plastral portion of the bridge prevents assessment of the shape of the axillary and inguinal processes, and the extension of their contact with pleurals. In the Miocene species, $M$. sarmatica and $M$. pygolopha, the inguinal processes reach about $1 / 3$ or less of Pl5-6, while the early Pliocene $M$. portisii presents reduced axillary buttresses, just joining the tip of Pl1, and narrow inguinal buttresses reaching less than 1/3 of P15-6 (Hervet, 2004).

Lapparent (2001) stated that two fossil groups can be identified in the record of Mauremys: one formed by the late Oligocenemiddle Miocene species and the other by the late Miocene-extant species. On the basis of the above mentioned comparisons and relationships, the Tuscan remains clearly represent a link in the phylogeny of the genus Mauremys, chronologically located between the Miocene group M. sarmatica-pygolopha and the Pliocene forms $M$. portisii and M. gaudryi (see Figs. 5, 6).

Faunal turnover in the latest Miocene Tusco-Sardinian area: comparison between mammal and chelonian taxa.-The latest Miocene continental record of the Italian peri-Tyrrhenian regions (Tuscany and Sardinia) documents the existence of a peculiar bioprovince characterised by the occurrence of vertebrate faunas with manifestly endemic features different from coeval mammal faunas either from European or African continental realm, the so-called 
TABLE 2-List of the reptilian and mammalian faunas present in V1-V3 assemblages of the late Miocene Tuscan localities. Note that the freshwater turtle families Geoemydidae and Trionychidae, and overall the terrapins ( $M$. campanii), are registered in all the three assemblages, not reflecting the large turnover suffered by the mammals; also note the appearance of terrestrial tortoises in the Messinian V3 assemblage.

\begin{tabular}{|c|c|c|c|c|}
\hline Family & Taxa & $\mathrm{V} 1$ & $\mathrm{~V} 2$ & $\mathrm{~V} 3$ \\
\hline \multicolumn{5}{|c|}{ Reptiles } \\
\hline \multicolumn{5}{|c|}{ CROCODYLIA } \\
\hline Crocodyidae & cf. Crocodylus sp. & $\mathrm{X}$ & $\mathrm{X}$ & \\
\hline \multicolumn{5}{|c|}{ TESTUDINES } \\
\hline Geoemydidae & Mauremys campanii & $\mathrm{X}$ & $\mathrm{X}$ & $\mathrm{X}$ \\
\hline Testudinidae & Testudo s.1. & & & X \\
\hline Trionychidae & Trionyx cf. T. pliopedemontanus & & & $\mathrm{X}$ \\
\hline Trionychidae & Trionyx sp. & $\mathrm{X}$ & $\mathrm{X}$ & \\
\hline \multicolumn{5}{|c|}{ "Large" Mammals } \\
\hline & PRIMATES & & & \\
\hline Hominoidea & Oreopithecus bambolii & $\mathrm{X}$ & $\mathrm{X}$ & \\
\hline Colobinae & Mesopithecus sp. & & & $\mathrm{X}$ \\
\hline \multicolumn{5}{|c|}{ ARTIODACTYLA } \\
\hline Suidae & Eumaiochoerus etruscus & $\mathrm{X}$ & X & \\
\hline Suidae & Propotamochoerus provincialis & & & $\mathrm{X}$ \\
\hline Giraffidae & Umbrotherium azzarolii & $\mathrm{X}$ & & \\
\hline Bovidae & Tyrrhenotragus gracillimus & $\mathrm{X}$ & $\mathrm{X}$ & \\
\hline Bovidae & ?Neotragini gen. et sp. indet. & & $\mathrm{X}$ & \\
\hline Bovidae & Marenumia haupti & $\mathrm{X}$ & & \\
\hline Bovidae & Maremmia lorenzi & & $\mathrm{X}$ & \\
\hline Bovidae & Etruria viallii & $\mathrm{X}$ & & \\
\hline Bovidae & Turriragus casteanensis & $\mathrm{X}$ & & \\
\hline Bovidae & ?Protoryx sp. & & & $\mathrm{X}$ \\
\hline Cervidae & Pliocervulus cf. P. australis & & & $\mathrm{X}$ \\
\hline Cervidae & Procapreolus cf. P. loczyi & & & X \\
\hline Cervidae & Tuscomeryx huerzeleri & & & $\mathrm{X}$ \\
\hline \multicolumn{5}{|c|}{ CARNIVORA } \\
\hline Mustelidae & Tyrrhenolutra helbingi & $\mathrm{X}$ & & \\
\hline Mustelidae & Paludolutra campanii & & $\mathrm{X}$ & \\
\hline Mustelidae & Paludolutra maremmana & & $\mathrm{X}$ & \\
\hline Mustelidae & Mustela majori & & $\mathrm{X}$ & \\
\hline Mustelidae & Plesiogulo crassa & & & $\mathrm{X}$ \\
\hline Ursidae & Indarctos laurillardi & & $\mathrm{X}$ & \\
\hline Felidae & Machairodus cf. M. giganteus & & & $\mathrm{X}$ \\
\hline Felidae & Metailurus major & & & $\mathrm{X}$ \\
\hline Hyaenidae & Hyaenidae indet. & & & $\mathrm{X}$ \\
\hline Viverridae & Viverra howelli & & & $\mathrm{X}$ \\
\hline \multicolumn{5}{|c|}{ PERISSODACTYLA } \\
\hline Tapiridae & Tapirus cf. T. arvernensis & & & $\mathrm{X}$ \\
\hline Equidae & Hippotherium sp. & & & $\mathrm{X}$ \\
\hline Rhinocerotidae & Stephanorhinus megarhinus & & & $\mathrm{X}$ \\
\hline
\end{tabular}

Tusco-Sardinian paleobioprovince (V1 and V2 faunal assemblages of the Oreopithecus Zone Faunas [OZF] in Bernor et al., 2001). The latest Miocene faunal succession of the Tusco-Sardinian area has been known for a long time in the literature, and the geological setting, the evolutionary patterns of mammals, and their biogeographic significance have been exhaustively reported in a number of papers (see Rook et al., 1999, 2000, 2006; Benvenuti et al., 2001; Abbazzi et al., 2008; Delfino and Rook, 2008 and literature therein).

A major reorganisation in the paleobiogeography of the Tyrrhenian area occurred during the Messinian. From a faunistic point of view, this time frame is characterised by a dramatic change. All mammal taxa belonging to the endemic faunal complex were replaced by a new faunal assemblage (known as V3) including continental taxa with clear European affinities (Hürzeler and Engesser, 1976; Rook, 1999; Rook et al., 2006). The V3 assemblage points to a renewed and definitive paleobiogeographical connection with Europe: the large mammals underwent a total replacement at the generic level (Table 2) and no single taxon from V1-V2 assemblages survived into the Messinian V3 assemblage. A peculiar characteristic of this turnover, appreciable in Table 2, is the different pattern shown among the herpetofauna by the chelonians. In contrast with large mammals, turtles survived with at least two freshwater genera, Mauremys and Trionyx, representing two different families (Geoemydidae and Trionychidae). The freshwater turtles seemed to be unaffected by the turnover that reshaped the mammal assemblages and survived into the Messinian, as shown by the record of M. campanii in the V3 assemblage (Table 2).

The presence of a third chelonian family in these pre-Messinian assemblages has been reported in the literature by Ristori (1895), who tentatively referred to Testudo? sp., some remains from Montebamboli and Casteani, on the basis of "the deep marks of growth annuli left by the horny shields" (Ristori, 1895: 85). MSNTUP-I10556 (partim), attributed by label to "Testudo ? sp.," probably represents the specimens seen by Ristori, but it clearly belongs to the terrapin $M$. campanii. Consequently, the presence of the family Testudinidae in the late Miocene Tuscany, is here considered as restricted to the latest Miocene (Messinian) V3 assemblage localities (Table 2): Cinigiano (Grosseto province; Testudo amiatae Pantanelli, 1893), Gretoni (Siena province; Testudo s.l.; Delfino, 2002), and Torrente Melacce, near Cinigiano (Testudo s.1.; Delfino, 2002).

Testudo s.l. is present in Italy only since the Messinian. In addition to the Tuscan V3 localities described in this paper, it is recorded from other sites: Santa Vittoria d'Alba (Cuneo province; Portis, 1879) and Cava Monticino (Brisighella, Ravenna province; Delfino, 2002). The arrival of Testudo s.l. could be possibly linked to the dispersal of new Messinian vertebrate assemblages into the Italian peninsula (Rook et al., 2006), a dispersal which in southern Tuscany characterises the V3 vertebrate assemblage. According to the fossil record as known at present, which is admittedly strongly biased by the rarity of early and middle Miocene localities, Italy represents the last region colonized by testudinids of the Testudo s.l. lineage, already present since MN1 in Spain, MN2 in Germany and in France, MN5 in Austria, and MN8 in Greece (Paraskevaïdis, 1955; Crusafont-Pairo and Golpe-Posse, 1974; Lapparent, 2002; Böhme and Ilg, 2003).

Palaeogeographic implications.-From the end of the middle Miocene (last occurrence of M. sarmatica; Tegel von Hernals and Türkenschanzplatz, Sarmatian age, MN7-8; Purschke, 1885; Glaessner, 1926) to the early Pliocene (Mauremys sp.; Montpellier, France, MN14; Bergounioux, 1933; M. portisii; Valleandona, Italy, Ruscinian, MN14-15; Sacco, 1889), Mauremys is present only as a few highly fragmentary remains in the Kohfidisch area (MN10; see Fig. 6) (Bachmayer and Mlynarski, 1983). Lapparent and Van Dijk (1999:149) stated that "during the end of the Miocene, between MN 6 [France] to MN 8 [Germany] and MN 13 [Italy, Spain] to MN 14-15 [southern France], Western Europe endured climatic changes such as increasing aridity, so that Mauremys [...] disappeared or was extremely reduced until MN 13" and wondered if Mauremys were still present in southern Europe and/or the eastern Mediterranean. The Tuscan remains answer this question by indicating, for the first time, the presence of $\mathrm{Mau}$ remys in southern Europe during a pre- and post-Messinian time frame and supporting the possibility of a dispersal from the Mediterranean into the Arabian Peninsula (Mauremys sp.; Baynunah Formation, Emirate of Abu Dhabi, Messinian, MN12-13; Lapparent and Van Dijk, 1999) and North Africa (M. leprosa; Aln Boucherit, Algeria, Ruscinian, MN14-15; Lapparent, 2000), as questioned by Lapparent and Van Dijk (1999) (Fig. 6).

There is evidence, from the distribution pattern of fossil reefbuilding z-corals in the Mediterranean, which suggests predominantly warmer temperatures through the early and middle Miocene, but with a sharp decline beginning in the early late Miocene (Tortonian) and continuing throughout the remaining Neogene (Esteban, 1996). The pattern of the fossil record of plants (KovarEder et al., 1996, 2008; Suc et al., 1999) and especially reefbuilding z-corals (Esteban, 1996; Rosen, 1999), suggests that eastern Mediterranean Europe (and especially the north Tyrrhenian 
area) was an area where warmer and possibly wetter conditions persisted longer than elsewhere in Europe. It has already been stressed that these conditions in Tyrrhenian insular environments made possible the maintenance of suitable habitats that influenced the survival/extinction of peculiar taxa (Rook et al., 2000). It is worth mentioning that no significant turnover can be detected within the European herpetofauna in the late Miocene and Pliocene of Europe (Delfino et al., 2003). Even for the Mio/Pliocene boundary, although global vegetation and faunal changes have been reported (Cerling et al., 1997, and reference therein quoted), modifications in the herpetological communities are apparently scattered along the transition. As already noticed in literature (Barbadillo et al., 1997; Rage, 1997; Delfino et al., 2003), the late Neogene herpetofauna, in comparison with the mammalian fauna, is apparently less affected by marked faunal changes.

At least at the family level, the herpetofauna simply seems to be dominated by a progressive decrease in diversity. The late Neogene herpetofauna consisted of a mixture of taxa that were mainly relics of the thermophilous Miocene fauna and a few new immigrants from Asia or North Africa (Bailon, 1991). The difference in the pattern of change shown by large mammals and herpetofauna at the transition between the V1-V2 faunas and the V3 assemblages (Table 2) is noticeable because of the deep significance of the mammalian turnover in terms of paleobiogeographic implication (Rook et al., 2006) and, at the same time, its congruence with the general pattern of the Cenozoic evolution of the herpetofauna (Delfino et al., 2003).

\section{ACKNOWLEDGMENTS}

E. Cioppi (Firenze), L. Costeur, B. Engesser, A. Ziems (Basel), F. Farsi (Siena), C. Nocchi, C. Sorbini (Pisa), C. Sarti (Bologna), D. Ormezzano (Torino), and R. Allain (Paris), kindly assisted the authors during the study of the collections under their care and provided useful information. A. Ohler (Paris) provided useful nomenclatural information, whereas P. Piras (Rome) provided suggestions for the cladistic analysis. M. Ferretti (Firenze), and the reviewers, U. Fritz (Dresden) and S. Hervet (Paris), significantly improved the manuscript. P. Pritchard (Oviedo, USA), J. Jadstrand and G. Ragnolo (Norwich) kindly revised the English grammar of an earlier draft. This paper is framed within a wider project on Late Neogene vertebrate evolution at the University of Florence (coordinator L.R.) for which the support of the University of Florence grants and the Researching Hominid Origins Initiative (NSF grant \#0321893) is gratefully acknowledged.

\section{REFERENCES}

Abbazzi, L., M. Delfino, G. Gallai, L. Trebini, And L. Rook. 2008. New data on the vertebrate assemblage of Fiume Santo (North-West Sardinia, Italy), and overview on the late Miocene Tusco-Sardinian palaeobioprovince. Palaeontology 51:425-451.

AMMON, L. V. 1911. Schildkröten aus dem Regensburger Braunkohlenton. Jahresbericht Naturwissenschaftlichen Vereins zu Regensburg, 12:1-35.

BACHMAYeR, F. AND M. MLynARSKI. 1983. Die Fauna der pontischen Höhlen- und Spaltenfüllungen bei Kohfidisch, Burgenland (Osterreich). Annalen des Naturhistorischen Museums in Wien, 85/A:107-128.

BAILON, S. 1991. Amphibiens et reptiles du Pliocène et du Quaternaire de France et d'Espagne: mise en place et évolution des faunes. Ph.D. dissertation, Université de Paris VII, 2 volumes, $499 \mathrm{p}$.

Barbadillo, L. J., M. Garcia-Paris, and B. Sanchiz. 1997. Origenes y relaciones evolutivas de la herpetofauna Iberica, p. 47-100. In J. M. Pleguezuelos (ed.), Distribucion y biogeografia de los anfibios y reptiles en España y Portugal. Monografías de Herpetología, Volumen 3. Universidad de Granada and Asociación Herpetológica Española, Granada.

Benvenuti, M., M. PAPINI, AND L. RoOK. 2001. Mammal biochronology, UBSU and paleoenvironment evolution in a post-collisional basin: evidence from the Late Miocene Baccinello-Cinigiano basin in southern Tuscany, Italy. Bollettino della Società Geologica Italiana, 120:97-118.

BergouniouX, F.-M. 1933. Monographie paléontologique de la faune de Vertébrés des Sables de Montpellier. II. Chéloniens. Travaux du Laboratoire de Geologie de la Faculte des Sciences de Lyon, 23(2):5-21.

BergouniouX, F.-M. 1936. Broilia manuascencis, nov. sp.: tortue paludine de l'Oligocène de Manosque. Bulletin de la Société Géologique de France, série 5, 6:59-62.

Bernor, R. L., M. Fortelius, AND L. RoOK. 2001. Evolutionary biogeography and paleoecology of the "Oreopithecus bambolii Faunal Zone" (Late Miocene, Tusco-Sardinian Province). Bollettino della Società Paleontologica Italiana, 40:139-148.

BöHME, M. AND A. ILG. 2003. fosFARbase. A relational database of lower vertebrates (fish, amphibians, and reptiles) from the Neogene of Eurasia. Available at www.wahre-staerke.com. Accessed March 11, 2008.

BusACK, S. D. AND C. H. ERNST. 1980. Variation in the Mediterranean populations of Mauremys Gray 1869 (Reptilia, Testudines, Emydidae). Annals of the Carnegie Museum, 49:251-264.

Cerling, T. E., J. M. Harris, B. J. MacFadden, M. G. Leakey, J. Quade, V. ElsEnMANN, AND J. R. EhLERINGER. 1997. Global vegetation change through the Miocene/Pliocene boundary. Nature, 389:153-158.

Chesi, F., M. Delfino, L. Abbazzi, S. Carboni, L. LeccA, And L. Rook. 2007. New fossil vertebrate remains from San Giovanni di Sinis (Late Pleistocene, Sardinia): the last Mauremys (Reptilia, Testudines) in the central Mediterranean. Rivista Italiana di Paleontologia e Stratigrafia, 113(2):287-297.

Crusafont-Pairo, M. AND J. M. GolPe-Posse. 1974. Nuevos yacimientos del Terciario continental del N.E. de España. Acta Geologica Hispánica, 9: 81-83.

DELFINO, M. 2002. Erpetofaune italiane del Neogene e del Quaternario. Ph.D. dissertation, Università degli Studi di Modena e Reggio Emilia, 382 p.

Delfino, M. AND L. Rook. 2008. African crocodylians in the Late Neogene of Europe: a revision of Crocodylus bambolii Ristori, 1890. Journal of Paleontology, 82(2):336-343.

Delfino, M., J. C. Rage, And L. Rook. 2003. Tertiary mammal turnover phenomena: what happened to the herpetofauna? Deinsea, 10:153-161.

DuMÉRIL, A. M. C. 1806. Zoologie analytique, ou méthode naturelle de classification des animaux, rendue plus facile à l'aide de tableaux synoptiques. Paris, $344 \mathrm{p}$

Esteban, M. 1996. An overview of Miocene reefs from Mediterranean areas: general trend and facies models, p. 3-53. In E. K. Franseen, M. Esteban, W. C. Ward, and J. Rouchy (eds.), Models for carbonate stratigraphy from Miocene reef complexes of Mediterranean region (SEPM Concepts in Sedimentology and Paleontology). Geological Society Publishing House, Tulsa.

FriTZ, U. AND P. HAVAš. 2007. Checklist of chelonians of the world. Vertebrate Zoology, 57(2):149-368.

Gaffney, E. S. And A. B. Meylan. 1988. A phylogeny of turtles, p. $157-$ 219. In M. J. Benton (ed.), The phylogeny and classification of the Tetrapods. Volume 1: Amphibians, Reptiles, Birds. Clarendon Press, Oxford.

GrAY, J. E. 1869. Notes on the families and genera of tortoises (Testudinata), and on the characters afforded by the study of their skulls. Proceedings of the Zoological Society of London, 1869:165-225.

GuAsparRI, G. 1992. Guida ai Musei. L'accademia dei Fisiocritici di Siena. Editoriale Donchisciotte, San Quirico d'Orcia, 166 p.

HeRvet, S. 2000. Tortues du Quaternaire de France: critères de détermination, répartitions chronologique et géographique. Mésogée, 58:3-47.

Hervet, S. 2003. Le groupe "Palaeochelys sensu lato-Mauremys" dans le contexte systématique des Testudinoidea aquatiques du Tertiaire d'Europe occidentale. Apports à la biostratigraphie et à la paléobiogéographie. Ph.D. dissertation, Muséum national d'Histoire naturelle de Paris. 619 p.

HERvET, S. 2004. Systématique du groupe «Palaeochelys sensu latu-Mauremys» (Chelonii, Testudinoidea) du Tertiaire d'Europe occidentale: principaux résultats. Annales de Paléontologie, 90:13-78.

Hervet, S. ANd F. DE Broin DE Lapparent. 2000. Palaeochelys mlynarski n. sp., de l'Oligocène supérieur de Rott (Allemagne), et redescription de l'espèce type P. bussenensis Meyer, 1847. Comptes Rendus de l'Académie des Sciences de Paris, Sciences de la Terre et des planetes, 331:563-569.

HiRAYAMA, R. 1985. Cladistic analysis of batagurine turtles (Batagurinae: Emydidae: Testudinoidea): a preliminary result. Studia Geologica Salmanticensia, vol. spec. 1(Studia Palaeocheloniologica1):141-157.

HüRZELER, J. AND B. ENGESSER. 1976. Les faunes de mammifères néogènes du Bassin de Baccinello (Grosseto, Italie). Comptes Rendus de l'Academie des Sciences de Paris, série 2, 283:333-336.

ICZN [INTERnational COMmission ON ZoOlogical Nomenclature]. 1999. International Code of Zoological Nomenclature. Fourth Edition. International Trust for Zoological Nomenclature, London, $306 \mathrm{p}$.

Kotsakis, T. AND D. MorI. 1981. Note di paleoerpetologia piemontese. I. I Cheloni del Messiniano superiore di Santa Vittoria d'Alba (Cuneo). Rivista Piemontese di Storia Naturale, 2:89-98.

Kovar-Eder, J., H. JechoreK, Z. KvačeK, And V. PARAshiv. 2008. The integrated plant record: an essential tool for reconstructing Neogene zonal vegetation in Europe. Palaios, 23(3):97-111.

Kovar-Eder, J., Z. Kvaček, E. Zastawniak, R. Givulescu, L. Hably, D. Mihajlovic, J. Teslenko, And H. Walther. 1996. Floristic trends in the vegetation of the Paratethys surrounding areas during Neogene time, $p$ 395-413. In R. L. Bernor, V. Fahlbush, and H.-W. Mittmann (eds.), The 
evolution of Western Eurasian Neogene mammal faunas III. Columbia University Press, New York.

Krenz, J. G., G. J. P. Naylor, H. B. Shaffer, and F. J. Janzen. 2005 Molecular phylogenetics and evolution of turtles. Molecular Phylogenetics and Evolution, 37:178-191.

Kunn, O. 1964. Fossilium catalogus. I: Animalia. Pars 107: Testudines. Fisher, Questedt, $300 \mathrm{p}$.

LaPPARENT, DE BRoIN DE, F. 2000. African chelonians from the Jurassic to the present: phases of development and preliminary catalogue of the fossil record. Palaeontologia Africana, 36:43-82.

LaPPARENT, DE BRoIN DE, F. 2001.The European turtle fauna from the Triassic to the present. Dumerilia, 4(3):155-218.

Lapparent, DE Broin DE, F. And P. P. VanDijk. 1999. Chelonia from the Late Miocene of Baynunah Formation, Emirate of Abu Dabi, A. Hill (ed.), Fossil vertebrates of Arabia. Yale University Press, New Haven.

MARTINI, I. P. AND M. SAGRI. 1993. Tectono-sedimentary characteristics of Late Miocene-Quaternary extensional basins of the Northern Apennines, Italy. Earth Science Review, 34:197-233.

MERCIAI, G. 1907. Sopra alcuni resti di vertebrati miocenici delle ligniti di Ribolla. Atti della Società Toscana di Scienze Naturali, Memorie, 23:79-87.

MerRem, B. 1820. Tentamen systematis amphibiorum. Krieger, Marburg, $191 \mathrm{p}$.

MeYeR, H. V. 1852. Mitteilungen an Prof. Bronn «Emys und Clemmys Arten in der von Haslach. ...». Neues Jahrbuch für Mineralogie, Geognosie, Geologie und Petrefaktenkunden, Briefwechsel, II, B:301-306.

PARASKEVAïDIS, I. 1955. Zwei Schildkrötenreste aus dem Obermiozän von Chios. Annales Géologiques des Pays Helléniques, 6:133-141.

Peters, K. F. 1868. Zur Kenntniss der Wirbelthiere aus den Miocänschichten von Eibiswald in Steiermark. I. Die Schildkrötenreste. Sitzungsberichte der Kaiserlichen der Akademie der Wissenschaften, Mathematisch-Naturwissenschaftliche Klasse, 57:72-74.

Pictet, F. J. AND A. Humbert. 1856. Monographie de la Molasse suisse; matériaux pour la paléontologie suisse. J. Kessmann, Genève, 71 p.

PoRTIS, A. 1879. Di alcuni fossili terziarii del Piemonte e della Liguria appartenenti all'ordine dei Chelonii. Memorie della Reale Accademia delle Scienze di Torino, serie 2, 32:113-134.

PuRSCHKE, C. A. 1885. Clemmys sarmatica $n$. sp. aus dem Tegel von Hernals bei Wien. Denkschriften der Kaiserlichen Akademie der Wissenschaften. Mathematisch-Naturwissenschaftliche Klasse, 50:185-192.

RAGE, J. C. 1997. Palaeobiological and palaeogeographical NMB-Background of the European Herpetofauna, p. 23-29. In J.-P. Gasc, A. Cabela, J. Crnobrnja-Isailovic, D. Dolmen, K. GrossenNMB-Bacher, P. Haffner, J. Lescure, H. Martens, J. P. Martínez Rica, H. Maurin, M. E. Oliveira, T. S. Sofianidou, M. Veith, and A. Zuiderwijk (eds.), Atlas of Amphibians and Reptiles in Europe. Societas Europaea Herpetologica and Muséum national d'Histoire naturelle (SPN/IEGB/MNHN), Paris.

REINACH, A. V. 1900. Schildkrötenreste im Mainzer Tertiärbecken und in benachbarten, ungefähr gleichalterigen Ablagerungen. Abhandlungen herausgegeben von der Senckenbergischen Natturforschenden Gesellschaft, 28:1-135.

RistoRI, G. 1891. I cheloniani fossili di Montebamboli e Casteani (Maremma, Toscana). Atti della Società Toscana di Scienze Naturali, Processi Verbali, 7:304-307.

RISTORI, G. 1895. Cheloniani fossili di Montebamboli e Casteani. Con appendice sui cheloniani fossili del Casino (Siena). Pubblicazioni della Facoltà di Scienze Matematiche Fisiche e Naturali dell'Università di Firenze, 21:1-104.

ROGER, O. 1902. Wirbelthierreste aus dem Obermiocän der bayerisch-schwäbischen Hochebene. Berichte des Naturwissenschaftlichen Vereins fur Schwäben und Neuburg, 35:1-63.

Rook, L. 1999. Late Turolian Mesopithecus (Mammalia, Primates, Colobinae) from Italy. Journal of Human Evolution, 36:535-547.

RoOK, L., L. ABbAZZI, AND B. ENGESSER. 1999. An overview on the Italian Miocene land mammal faunas, p. 191-204. In J. Agustí, L. Rook, and P. Andrews (eds.), The evolution of Neogene terrestrial ecosystems in Europe. Cambridge University Press, Cambridge.

ROOK, L., G. GALlaI, AND D. TORRE. 2006. Lands and endemic mammals in the Late Miocene of Italy: constrains for paleogeographic outlines of Tyrrhenian area. Palaeogeography, Palaeoclimatology, Palaeoecology, 238:263-269.

Rook, L., P. RenNe, M. Benvenuti, AND M. PAPINI. 2000. Geochronology of Oreopithecus-bearing succession at Baccinello (Italy) and the extinction pattern of European Miocene hominoids. Journal of Human Evolution, 39: 577-582.

Rosen, B. R. 1999. Palaeoclimatic implications of the energy hypothesis from Neogene corals of the Mediterranean region, p. 309-327. In J. Agustí, L. Rook, and P. Andrews (eds.), The evolution of Neogene terrestrial ecosystems in Europe. Cambridge University Press, Cambridge.

RÜTIMEYER, L. 1876. Über Pliocän und Eisperiode auf beiden Seiten der Alpen. H. Georg's Verlag, Basel, 80 p.

SACCO, F. 1889. I Cheloni astiani del Piemonte. Memorie della Reale Accademia delle Scienze di Torino, serie 2, 39:427-461.
Spinks, P. Q., H. B. Shaffer, J. B. Iverson, AND W. P. McCord. 2004 Phylogenetic hypotheses for the turtle family Geoemydidae. Molecular Phylogenetics and Evolution, 32:164-182.

Suc, J.-P., S. Fauquette, M. Bessedik, A. Bertini, Z. Zheng, G. Clauzon, D. Suballyova, F. Diniz, P. Quezel, N. Feddi, M. Clet, E. Bessais, N. Bachiri TaoufiQ, H. Meon, and N. Combourieu-Nebout. 1999. Neogene vegetation changes in West European and West circum-Mediterranean areas, p. 378-388. In J. Agustí, L. Rook, and P. Andrews (eds.), The evolution of Neogene terrestrial ecosystems in Europe. Cambridge University Press, Cambridge.

SwOFFord, D. L. 2002. PAUP*. Phylogenetic analysis using parsimony (*and other methods). Version 4.0b10. Sinauer Associates, Sunderland.

Weithofer, A. 1888. Alcune osservazioni sulla fauna delle Ligniti di Casteani e Montebamboli (Toscana). Bollettino del Reale Comitato Geologico d'Italia, 11- 12:363-368.

\section{ACCEPTED 18 NOVEMBER 2008}

\section{APPENDIX 1}

List of terrapin fossil remains now referred to Mauremys campanii, from Casteani, Montebamboli, Pian Calcinaio, and deposited in the museum collections listed in the section "Materials and methods." The latest taxonomic attribution is shown in parentheses.

Casteani (V1)-IGF: 4099V ("E. depressa"-Ristori, 1895, pl. 5, fig. 24), 4108V ("E. depressa"-Ristori, 1895, pl. 4, fig. 25), 4109V ("E. depressa" by label), $4110 \mathrm{~V}$ ("E. depressa" by label), 4111V ("E. depressa" by label), $11759 \mathrm{~V}$ ("E. depressa"-Ristori, 1895, pl. 5, fig. 26), 11760V ("E. depressa" by label), $11761 \mathrm{~V}$ ("E. depressa"-Ristori, 1895, pl. 6, fig. 31), 11762V ("E. depressa"-Ristori, 1895, pl. 3, figs. 14, 15); MSNAFS: 2629 ("Lignite con?" by label), 2636 ("E. depressa", Guasparri, 1992, fig. 32), 2637 ("E. parva" by label), 2639 ("E. parva" by label); MSNTUP: I10488 ("E. campanii"-Ristori, 1895, pl. 4, figs. 20, 22), I10494 ("E. depressa" by label), I10556 (partim) ("Testudo? sp." by label).

Montebamboli (V2)—IGF: 4103V ("Emys sp." by label); MSNAFS: 2174 ("Trionyx sp." by label), 2176 ("E. depressa" by label), 2177 ("E. depressa" by label); MSNTUP: I10487 ("E. campanii"-Ristori, 1895, pl. 4, figs. 18 , 21), I10490 ("E. campanii"-Ristori, 1895, pl. 6, figs. 28, 29), I10491 ("E. depressa" by label), I10493 ("E. campanii" by label), I10496 ("E. parva" Ristori, 1895, pl. 6, fig. 30), I10553 ("E. depressa" by label).

Pian Calcinaio (V3)—NMB-Bac: 1229 ("Mauremys sp."-Delfino, 2002, pl. 18, figs. C-M, pl. 19, figs. A-C).

Hexagonal neurals, pleurals, peripherals and indeterminate shell fragments are tentatively referred to the same taxon, $M$. campanii, despite the absence of diagnostic features:

Casteani (V1)-IGF: 4100V ("E. campanii" by label), 4101V ("E. campanii" by label), 4104V ("Emys sp." by label), 4105V ("Emys sp." by label), $4112 \mathrm{~V}$ ("E. depressa" by label); MGUB: 8890 ("Testudo sp." by label) MSNAFS: 2616 ("Emys sp." by label), 2617 ("Emys sp." by label), 2618 ("E. campanii" by label), 2630 ("Emys sp." by label), 2631 ("Emys sp." by label), 2632 ("Emys sp." by label), 2633 ("E. campanii" by label), 2638 ("Emys sp." by label); MSNTUP: I10547 (“Emys sp."-Merciai, 1907, pl. 4, fig. 8).

Montebamboli (V2)_IGF: 4102V ("E. campanii" by label), 4103V ("Emys sp." by label), 4106V ("Emys sp." by label), 4107V ("Emys sp." by label), 4113V ("E. depressa" by label); MSNAFS: 2093 ("Testudines indet." by label), 2097 ("Testudines indet." by label), 2098 ("Testudines indet." by label), 2100 ("Trionyx sp." by label), 2115 ("Formazione miocenica" by label), 2178 ("E. campanii" by label), 2179 ("Emys sp." by label), 2180 ("Emys sp." by label), 2181 ("E. campanii" by label), 2182 ("Emys sp." by label); MSNTUP: I10486 ("E. parva"-Ristori, 1895, pl. 4, figs. 19, 23), I10492 ("Emys sp." by label), I10496 ("Testudines indet." by label), I10497 ("Testudines indet." by label), I10498 ("Testudines indet." by label), I10557 ("Testudines indet." by label), I13278 ("E. parva"-Ristori, 1895, pl. 3, fig. 16), I13279 ("Testudines indet." by label), I13281 ("Testudines indet." by label), I13287 ("Emys sp." by label), I13289 ("Testudines indet." by label), I13290 ("Testudines indet." by label), I13293 (partim) ("Testudines indet." by label), I13305 ("Testudines indet." by label), I13306 ("Testudines indet." by label).

\section{APPENDIX 2}

Character codings of Mauremys campanii and M. portisii for morphological characters used in the phylogenetic analysis. For character description see Hervet (2003).

Mauremys campanii

14 ?12221111111?110110(012) 3112111?2?212111?11122222104??11 Mauremys portisii 1??0211101111??11001023113?11?2?2121110111222221031?11 